\title{
Migrant physicians' entrance and advancement in the Swedish medical labour market: a cross-sectional study
}

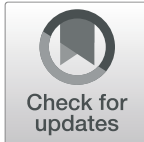

\author{
Linda Sturesson $^{1 *} \mathbb{D}$, Magnus Öhlander ${ }^{2}$, Gunnar H. Nilsson³ ${ }^{3}$ Per J. Palmgren ${ }^{1}$ and Terese Stenfors ${ }^{1}$
}

\begin{abstract}
Background: Worldwide, physicians are migrating to new countries and want to practise their profession. However, they may experience difficulties doing so. To optimise and accelerate their entrance into and advancement within the Swedish healthcare system, there is an urgent need to explore how they are currently doing so, as their competences should be put to use without any unnecessary delay. The aim of the study was to explore how migrant physicians with a medical degree from outside EU/EEA enter and advance within the medical labour market in Sweden and to identify perceived barriers and facilitating aspects in the process. The empirical findings are discussed in light of Bourdieu's concept symbolic capital as adapted in the Swedish medical field.
\end{abstract}

Methods: A cross-sectional study with a self-administrated questionnaire was disseminated. A sample of 498 migrant physicians were identified. Descriptive statistical analysis and qualitative thematic analysis were used to analyse the data.

Results: The response rate was 57\% $(n=283)$. Respondents mainly found their first positions via spontaneous job applications, during internships, while participating in an educational intervention or via personal contacts. Perceived barriers to entering and advancing within the medical field in Sweden were mainly related to having a medical degree from and/or originating from another country, which could in turn represent discrimination and/or having one's competence undervalued as a result. Facilitating aspects included having or developing contacts in Swedish healthcare and gaining proficiency or fluency in the Swedish language.

Conclusions: When MPs find their first positions, the contacts they have developed appear to play a role, and when advancing in their positions, the active development of a variety of contacts seems to be beneficial. MPs experience a variety of barriers to entering and advancing within the field that could be related to discrimination. Many MPs perceived having their competences undervalued due to their origin or to being educated abroad. Based on the respondents' experiences, our interpretation is that MPs as a group are hierarchically positioned lower in the Swedish medical field than physicians trained in the country. Facilitating aspects included educational interventions, having contacts and developing language skills. For optimal entry into the labour market, it is vitally important for MPs to learn the new language and obtain a job or internship in the field as soon as possible.

\footnotetext{
* Correspondence: linda.sturesson@ki.se

${ }^{1}$ Department of Learning, Informatics, Management and Ethics, Karolinska

Institutet, 17177 Stockholm, Sweden

Full list of author information is available at the end of the article
}

(c) The Author(s). 2019 Open Access This article is distributed under the terms of the Creative Commons Attribution 4.0 International License (http://creativecommons.org/licenses/by/4.0/), which permits unrestricted use, distribution, and reproduction in any medium, provided you give appropriate credit to the original author(s) and the source, provide a link to the Creative Commons license, and indicate if changes were made. The Creative Commons Public Domain Dedication waiver (http://creativecommons.org/publicdomain/zero/1.0/) applies to the data made available in this article, unless otherwise stated. 


\section{Introduction}

For migrant physicians (MP) with a medical degree from abroad who want to enter the medical labour market in their new country as practising physicians, different routes and interventions have been developed [1-8]. Empirical investigations on MPs often focus on their arrival and the early stages of recertification processes $[1$, 9], on educational interventions $[1,10]$ or on challenges, barriers and facilitating factors for workplace integration, i.e. when MPs have found employment [1, 9-14].

Less research exists on the process between an educational intervention and/or recertification and employment, although available findings indicate that MPs struggle to find employment $[8,15]$. One barrier to entering the labour market for migrants is discrimination $[8,16-20]$, especially for those from non-western countries [17-20]. Highly skilled migrants are no exception $[19,21]$. Some have experienced being undervalued at work despite their education [22]. This might also occur during the job-seeking process (cf. [23]), yet this issue has not been thoroughly explored. Other barriers to employment include a lack of knowledge about how to apply for work or how to act in a job interview, as well as language problems [19]. Also, as the recertification process takes time, many MPs are often older than peers educated in the new country [8, 19], and they might have families which can make it more difficult to study (cf. [8]). Empirical evidence also suggests that having children is a barrier as it reduces possibilities to move [19] to for example rural and remote areas where the absence of physicians are common, and MPs seem to prefer to live and work in urban areas [1, 24-26].

In Sweden, MPs trained outside the EU/EEA, as well as physicians trained in Sweden, have to apply for and complete a mandatory medical internship (MMI) and must pass an assessment before they can obtain a Swedish licence to practise. The number of MMI positions is, however, limited, which in turn results in longer waiting times [27]. Governmental reports suggest that MPs take longer than their Swedish-educated peers to obtain their Swedish licence to practise [28]. This may be because MPs lack the networks that might be needed to secure an MMI position [28].

From a societal and individual perspective, it is crucial that non-EU medical educated MPs' competences can be put to use in the labour market without any unnecessary delay. To optimise and accelerate MPs' entry into the Swedish healthcare system, there is an urgent need to explore how MPs currently enter into and advance within the system. Thus, the aim of this study is twofold: (1) to explore how MPs enter into and advance within the medical labour market in Sweden and (2) to identify perceived barriers and facilitating aspects for entrance into and advancement within the Swedish medical labour market.
One way to explore how MPs becomes a part of the Swedish medical workforce and advance within the medical labour market is to employ the concepts of social field and symbolic capital developed by Bourdieu [29, 30]. Simply put, a social field can be defined as a limited system of relations between social positions (individuals) with shared interests. In this article, we will use the concept medical field. The medical field comprises different kinds of medical professionals, positions for whom are allocated based on negotiations about common interests, including characteristics of medical science, medical work or medical competence [31]. Different types of symbolic capital, which can be cultural, social or economic, position individuals hierarchically in a given field. When capital is recognised in a specific field, it becomes symbolic capital, which thereafter defines a person's position and possibilities within that field. Having a recognised education and degree, as well as requisite skills and knowledge, can be understood as conferring symbolic capital (cultural). Symbolic capital (social) can also manifest as a valuable and useful network within a profession. To be counted as symbolic capital, however, such a network should potentially lead to a gain-for example, employment (cf. [32]). Blain et al. (2016) suggested that symbolic resources influence opportunities for MPs to work in a medical field [33]. Having social capital in the form of a useful social network may thus facilitate employment.

The medical field can be understood as transnational, as it extends beyond national borders, and physicians can practise their profession in different countries [34]. However, a smooth transition from one country's medical field to that of another country cannot be guaranteed. In the process of migration, a professional's capital has to be recognised in the new country's specific medical field. Depending on where a medical degree is acquired, its accompanying cultural and social capital might not be valued equally. For example, when physicians with a medical degree from outside the EU/EEA want to enter the medical field in Sweden as independently practising physicians, their medical degrees must be formally acknowledged before they can acquire a Swedish medical licence. Thus, MPs' symbolic capital can, based on jurisdiction, be seen as being devalued when transferred to a new country's medical field (cf. [23]). Accordingly, MPs must have their capital recognised and create new capital, which can be termed migration-specific capital [35]. Migrants also actively develop a 'mechanism of validation for their cultural capital' in the bargaining process when trying to enter the field [35]. One validation route is the institutionalised Complementary Program for Physicians (CPP). Via the CPP, MPs are expected to develop the countryspecific competence needed to obtain a Swedish medical 
licence to practise. In this new country, with its dominant culture, MPs must further develop their symbolic capital for it to be of any real value (cf. [35]). The cultural capital (e.g. education, skills and knowledge) developed in another country's medical field might represent a barrier if it is valued less than that of the new country.

\section{Methods}

For our research, we applied a cross-sectional study design. A questionnaire was distributed to a sample of MPs in Sweden who possessed a medical degree from outside the EU/EEA or Switzerland.

\section{Context}

Physicians with a medical degree from outside the EU/ EEA or Switzerland can follow three routes to obtaining a Swedish licence to practise: (1) take a proficiency test and pass a course in Swedish laws and regulations, after which they must find and complete 6 months of clinical training; (2) participate in the CPP for 10 months; and/ or (3) participate in Swedish medical education.

Routes 1,2 and 3 can be seen as one phase in the licencing process. Until June 2016, all three routes had to be followed by another, stand-alone, phase: the 18-21month MMI, which is assessed by a test. After July 2016, the MMI are however only applicable to those beginning route 2 or 3 after July 2016.

Some MPs change routes. For example, an MP may begin route 2 (CPP) but then take the proficiency test (route 1) to accelerate the licencing process. Before the CPP and the MMI, and before obtaining the Swedish licence to practise, MPs (as well as physicians educated in Sweden) may work as junior doctors, which is a restricted position before being licenced.

\section{Participants and sampling}

Potential participants for this study included MPs with a medical degree from outside the EU/EEA or Switzerland who enrolled in the CPP (route 2) during the 2009-2017 admission years-in total, 498 MPs. Route 2 was selected due to access to demographic data. (Unfortunately, one was deceased) $\mathrm{CPP} /$ route 2 potential participants were identified via registry data provided by the universities giving the programme. The sampling strategy was nonprobabilistic and had the potential to include the whole population of route 2 participants, giving them an equal opportunity to participate in the study so long as they had updated their contact details in the registry. In Fig. 1, a detailed sampling frame is presented.

Participation was voluntary, and written informed consent was obtained from the participants. All collected data were anonymised to maintain the integrity of the individual respondents, and the data were handled and stored in accordance with the tenets of the World
Medical Association Declaration of Helsinki (2008). The Regional Ethical Review Board in Stockholm, Sweden, approved the study $(2017 / 1717-31 / 5)$.

\section{Data collection}

A self-administered questionnaire was developed to fit our aim. The questionnaire was developed following a seven-step process outlined by Artino et al. [36], as presented in Table 1.

The final questionnaire comprised the following sections: participants' backgrounds and previous experiences, entrance into the labour market, interventions and the MMI. The questionnaire was composed in Swedish and included open-ended questions without character limitations and close-ended questions with binary, nominal or ordinal response options. Depending on the participants' responses, different follow-up questions were used. Hence, no respondent received the exact same set of questions. The questionnaire was distributed digitally and answered during February and March 2019. The sampling frame in Fig. 1 presents the process, the number of reminders and the number of potential and actual respondents.

\section{Data analysis}

The completed questionnaires were exported to Excel. Descriptive statistics, which formed the backbone of the statistical analysis, were conducted on categorical data, which were subsequently presented as frequencies and percentages. The responses to closed- and open-ended questions were analysed to complement the quantitative results and deepen knowledge on the topic (cf. [40-42]). Thematic content analysis was used in this process [43]. The responses were read through for familiarisation, and significant sentences and/or keywords were identified and noted; then, central concepts were deductively grouped into the identified preset themes of used strategies, experiences of discrimination and valuing of competence (Table 1) (cf. [44]). The text answers were also analysed inductively to identify other themes related to barriers and facilitative aspects in the respondents' answers (cf. [42, 44]). The findings were iteratively discussed between the authors to enhance credibility. Quotations were translated into English and edited to increase readability and protect confidentiality, without sacrificing the content or its meanings.

\section{Results}

We present the results as follows: 'Response and respondents' demographics', 'How MPs enter into and advance within the medical labour market in Sweden', 'Experienced barriers' and 'Facilitating aspects'. 
Complementary Program for Physicians (CPP) with a medical degree from outside EU/EEA

Population: $498-1$ deceased $=497$

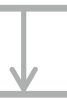

No information of email address: 5

Text message asking about email address: 2

Emails/questionnaires sent out in total: 493

(A random selection of $31 \mathrm{MPs}$ received the questionnaire prior to the remaining respondents to ensure the functionality of the survey tool; then the rest of the emails were sent out)

Email undeliverable and unidentifiable: 13

Response including email address: 1

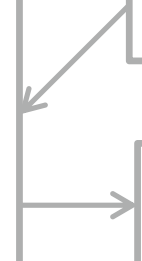

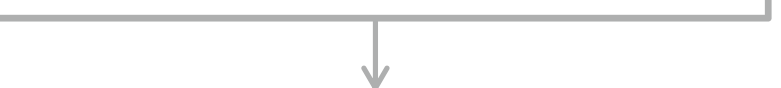

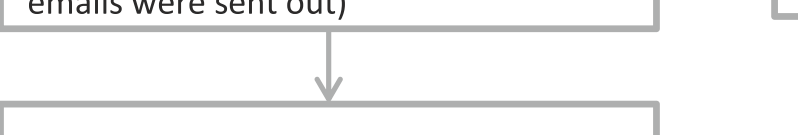

Reminders sent out: 3

MPS who had begun answering the questionnaire, but who had not submitted their answers, were encouraged to do so in a separate reminder.
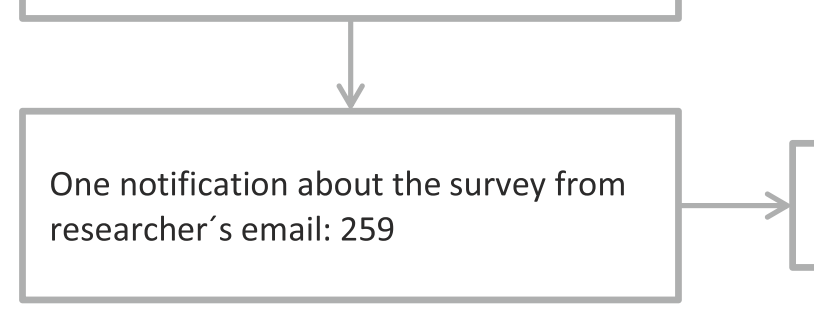

Identified emails as undelivered: 9 (of the 13 above)

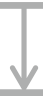

Text message asking about email address: 7

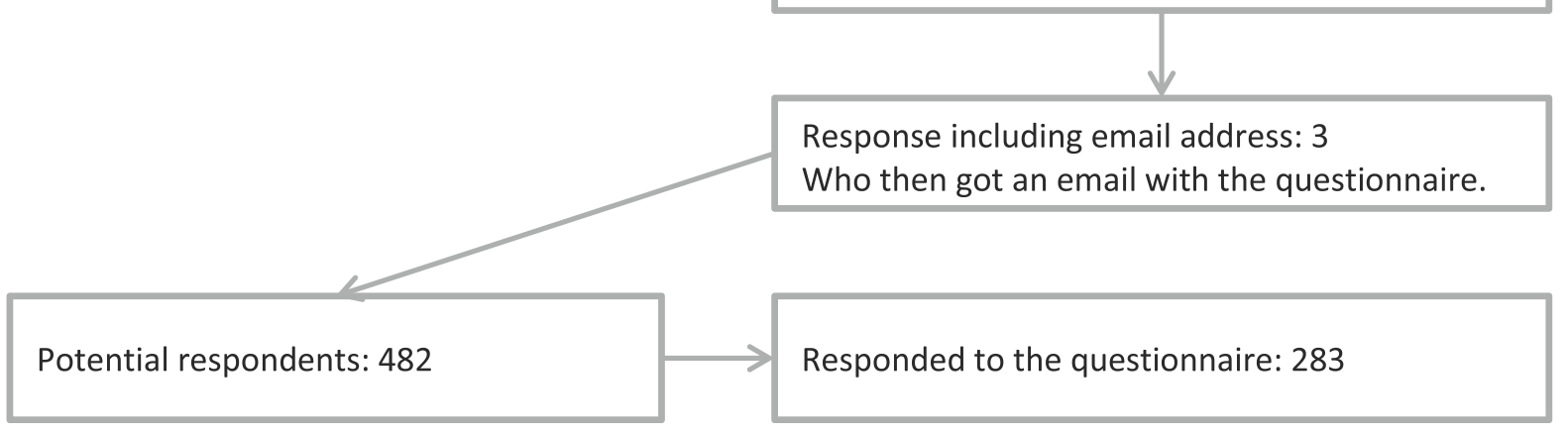

Fig. 1 Sampling frame 
Table 1 Development of the questionnaire

\begin{tabular}{|c|c|c|}
\hline Step & & Procedure \\
\hline 1 & $\begin{array}{l}\text { Literature } \\
\text { review }\end{array}$ & $\begin{array}{l}\text { When conducting the literature review, little empirical knowledge was identified regarding MPs' pathways into the } \\
\text { labour market in Sweden. }\end{array}$ \\
\hline 2 & Interviewing & $\begin{array}{l}\text { In a process parallel to the literature review, } 24 \text { participants from the CPP were interviewed at the beginning of } \\
\text { the programme and after completing it ( } n=16) \text {. Informal interviews with experts, such as recruitment staff, a } \\
\text { physicians' trade union, researchers and responsible persons from the CPP, were also conducted ( } n=7) \text {. }\end{array}$ \\
\hline 3 & Synthesising & Themes for further investigation were developed based on the literature review and interviews. \\
\hline 4 & $\begin{array}{l}\text { Item } \\
\text { development }\end{array}$ & The themes were described, and questions as well as response scales were developed and discussed continuously [37-39]. \\
\hline 5 & Feedback & $\begin{array}{l}\text { Questions were presented and critically discussed in different forums (e.g. research seminars) to obtain feedback on the } \\
\text { themes, questions and wordings, as well as to streamline the questionnaire, fill any gaps and reduce redundant questions. }\end{array}$ \\
\hline 6 & $\begin{array}{l}\text { Cognitive } \\
\text { interviews } \\
\text { (Cls) }\end{array}$ & $\begin{array}{l}\text { The constructed questions and response scales were discussed during individual interviews with six physicians, who were } \\
\text { migrants not educated in Sweden (except one). After the cognitive interviews, the questionnaire was further improved } \\
\text { regarding wording, formulation and response alternatives. }\end{array}$ \\
\hline 7 & Pilot test & $\begin{array}{l}\text { I) The questionnaire was constructed digitally with a survey tool and sent out for pretest to } 23 \text { individuals. In this pretest, } \\
16 \text { respondents provided feedback on the logic in the questionnaire, as well as on the questions and response alternatives. } \\
\text { The respondents consisted of researchers, people responsible for or working with the CPP, and others with relevant expertise. } \\
\text { The questionnaire was thereafter further improved. } \\
\text { II) The questionnaire was sent out for a pilot test to } 24 \text { physicians working in Sweden who were at different stages in their } \\
\text { careers; however, this did not include a sample from the MPs selected for participation in the study. Some of the respondents } \\
\text { in the pilot study had their medical education in Sweden. Fifteen of the } 24 \text { responded in the pilot. In the pilot, the respondents } \\
\text { answered the questionnaire, but they also had the opportunity to provide feedback on the questionnaire, questions and } \\
\text { wording. The results and comments from the pilot were discussed during two research meetings with different participants, } \\
\text { and the questionnaire was refined twice more before use. }\end{array}$ \\
\hline
\end{tabular}

\section{Response and respondents' demographics}

The questionnaire had a $57 \%$ response rate $(n=283)$ (Table 2). The internal non-response bias was less than $10 \%$ on each question. The number of respondents $(n)$ varied since the physicians were at different stages in their careers, and thus, not every question was relevant for everyone. Comparing all the participants who had begun the CPP, the distribution was equal regarding gender, year of birth and frequency of obtained Swedish medical licences. The respondents had resided in Sweden for an average of 10.3 years at the time the questionnaire was administered $(n=274)$. Respondents' demographics are presented in Table 3.

Of the respondents, 61\% had worked in Swedish healthcare previous to enrolling in the CPP, on average for 20 months. Most had worked as assistant nurses, but some also held jobs as medical assistants and care assistants. A few had worked as junior doctors (a restricted position available before being licenced) or administrators, and some had worked as nurses, interpreters, in research or teachers of related healthcare-related subjects. Also, some respondents had taken internships and/ or had been auscultating. It was common to have held several different positions.

When answering the questionnaire, $88 \%$ of the respondents currently held a position as a physician but were in different stages of their careers, as they had also started the CPP in different years (Table 4).

Of the respondents, $12 \%(34, n=283)$ did not hold a position as a physician in Sweden when answering the

Table 2 Distribution of eligible respondents and respondents by gender, birth year and possession of medical licence

\begin{tabular}{llll}
\hline & Category & $\begin{array}{l}\text { Respondents } \\
(n=283(\%))\end{array}$ & $\begin{array}{l}\text { Number of participants in the Complementary Program for Physicians (CPP) with a medical } \\
\text { degree from outside the EU/EEA }(n=498(\%))\end{array}$ \\
\hline Gender* & Females & $153(54)$ & $264(53)$ \\
& Males & $130(46)$ & $234(47)$ \\
Year of birth* & $<1970$ & $29(10)$ & $67(13)$ \\
& $1971-$ & $104(38)$ & $183(37)$ \\
& 1980 & & $248(50)$ \\
Mean age & $1981>$ & $146(52)$ & 40 years \\
Obtained Swedish & Yes & $112(40)$ & $197(40)$ \\
medical licence & No & $171(60)$ & $301(60)$
\end{tabular}

*Registry data 
Table 3 Distribution of respondents' demographics

\begin{tabular}{|c|c|c|c|}
\hline & Category & $\begin{array}{l}\text { Frequency } \\
(\%)\end{array}$ & Comment \\
\hline \multirow[t]{5}{*}{ Region of origin } & Asia & $132(55)$ & \multirow{5}{*}{$\begin{array}{l}\text { The respondents }(n=241) \text { represented } 43 \text { countries (including Sweden). } \\
\text { Some had grown up in more than one region. }\end{array}$} \\
\hline & Europe & $64(27)$ & \\
\hline & Africa & $32(13)$ & \\
\hline & $\begin{array}{l}\text { Latin America and } \\
\text { the Caribbean }\end{array}$ & $21(9)$ & \\
\hline & North America & $2(1)$ & \\
\hline \multirow[t]{4}{*}{ Region of medical education $(n=263)$} & Asia & $131(49)$ & \multirow{13}{*}{$\begin{array}{l}\text { The number of countries for education was } 52(n=269) \text {. Some } \\
\text { participants mentioned more than one country. }\end{array}$} \\
\hline & Europe & $88(33)$ & \\
\hline & Africa & $28(10)$ & \\
\hline & $\begin{array}{l}\text { Latin America and } \\
\text { the Caribbean }\end{array}$ & $21(8)$ & \\
\hline \multirow{3}{*}{$\begin{array}{l}\text { Year of graduation from medical } \\
\text { education }(n=270)\end{array}$} & 2000 or before & $50(19)$ & \\
\hline & $2001-2010$ & $142(53)$ & \\
\hline & 2011 or later & $78(29)$ & \\
\hline \multirow{6}{*}{$\begin{array}{l}\text { Years worked as a physician before } \\
\text { migrating to Sweden }(n=279)\end{array}$} & None & $53(19)$ & \\
\hline & Less than 1 year & $41(15)$ & \\
\hline & $1-2$ years & $88(32)$ & \\
\hline & $3-5$ years & $68(24)$ & \\
\hline & $6-10$ years & $19(7)$ & \\
\hline & More than 10 years & $10(45)$ & \\
\hline
\end{tabular}

questionnaire, but some held other jobs in the healthcare field or worked as physicians outside of Sweden. A few were unemployed, on parental leave or travelling.

\section{How MPs enter into and advance within the medical labour market in Sweden}

Of the respondents who had applied for a position as a physician after the CPP $(n=265,249$ working as physicians, and 16 not working as physicians), $42 \%$ had applied for $1-5$ positions, $9 \%$ for $6-10$ positions, $8 \%$ for 11-20 positions and $8 \%$ for $21-50$ positions. Five percent of the respondents had applied for 51 or more positions. Of the respondents, $29 \%$ stated that they did not need to apply for work. In Table 5, the different channels used by respondents to find their first job as a physician are presented.
In most cases, the first job for the respondents $(n=$ 263) after the CPP was as a junior doctor $(88 \%, n=232)$, while $3 \%(n=9)$ worked as medical assistants. The ideal position after having completed route 1 or route 2 (the CPP) was, however, the MMI, which was the first position for $3 \%(n=7)$ of the respondents. The average time to begin the MMI (waiting time) was 16 months ( $n=$ $179)$ and, in the largest urban area, 20.4 months $(n=29)$. One quarter $(26 \%)$ of the 248 respondents who held a position as a physician (junior doctor, medical assistant or had an MMI) as their first position after the CPP got their first job offer during the CPP. One half of these respondents got their first job offer 0-3 months after completing the CPP (route 2) or route 1 (some had changed routes). After 4-6 months, $12 \%$ had received and accepted a job after having completed the CPP or

Table 4 Distribution of respondents $(n=249)$ with a position as a physician by type of position

\begin{tabular}{|c|c|}
\hline Position & Frequency (\%) \\
\hline Junior doctor position (before the mandatory medical internship) & $64(26)$ \\
\hline Mandatory medical internship position & $65(26)$ \\
\hline Junior doctor position (after the mandatory medical internship and without having obtained the Swedish medical licence) & $7(3)$ \\
\hline Junior doctor position (after the mandatory medical internship and having obtained the Swedish medical licence) & $11(4)$ \\
\hline Specialty training position & $94(38)$ \\
\hline Specialist position or senior doctor position & $8(3)$ \\
\hline
\end{tabular}


Table 5 Distribution of respondents $(n=257)$ who received their first position as a physician after the CPP

\begin{tabular}{lll}
\hline $\begin{array}{l}\text { Type of information }(\%, \text { of } n, \% \text { of answers in total } \\
n=327)\end{array}$ & Sub-types & $\begin{array}{l}\text { Frequency }(\% \text { of } n, \% \text { of answers in total } \\
n=327)\end{array}$ \\
\hline Contact with employer $(68,54)$ & Spontaneous job applications & $73(28,22)$ \\
& During internship CPP (route 2) & $63(25,19)$ \\
& Work previous to the CPP & $24(9,7)$ \\
& During internship during route 1 (possible for 25 & $15(6,5)$ \\
& respondents) & \\
& Via friends & $35(14,11)$ \\
Personal contacts $(23,30)$ & With study peers from the CPP & $22(9,7)$ \\
& Via family or relatives & $10(4,3)$ \\
& Via teachers in the CPP & $6(2,2)$ \\
Labour office $(6,8)$ & Via mentor, coach or sponsor & $3(1,<1)$ \\
Job advertisements $(13,17)$ & & $21(8,6)$ \\
& Country Council webpage & $22(9,7)$ \\
Social network contacts $(2,3)$ & Employer's webpage & $17(7,5)$ \\
& Physicians Union Paper & $4(2,1)$ \\
& Linkedln & $3(1,<1)$ \\
& Chat groups with other MPs & $2(<1,<1)$ \\
& Recruitment fair & $1(<1,<1)$ \\
& Staffing agencies & $1(<1,<1)$ \\
\hline
\end{tabular}

CPP denotes Complementary Program for Physicians with a medical degree from outside the EU/EEA or Switzerland

route 1 ; for $7 \%$, it took 7 months or more. For a few respondents, their first job was as an assistant nurse, but they had also held other jobs.

\section{Experienced barriers}

We found several barriers to entering and advancing within the medical field in Sweden (Table 6). The themes of having another ethnicity and/or religion or other belief, having a different name, insufficient language skills, having the wrong age and having the wrong gender are associated with discrimination in Sweden [45]. In total, $29 \%$ of the respondents perceived having been disfavoured based on grounds related to discrimination during their job-seeking processes. The distribution of their experiences was equal in terms of gender and total respondents (Table 2): 44 women (54\%) and 38 men (46\%). However, there were some gender differences with respect to different grounds for discrimination, as displayed in Table 6. The answers showed that perceptions of having been disfavoured were related to several factors-for example, ethnicity, religion and gender.

Experienced barriers also included having one's competence undervalued during the job-seeking process, which some respondents associated with originating from another country and/or having a medical degree from abroad, insufficient language skills and lacking work experience and work references from Sweden. In some comments, perceptions of having been disfavoured and having competences undervalued both occurred. For example, one respondent applying for the MMI stated:

Very little chance of succeeding despite letters of recommendation $[. .$. ] and good references since I have worked in psychiatry, which is not so much merit for [MMI] and you do not give so much importance to my placements in the home country. Discrimination against foreign doctors and questioning the competences you have on your $\mathrm{CV}$ does not help either. One needs to show competence and become overloaded in practice before the employer trusts a foreign doctor, unfortunately. Therefore, foreign workers are most often employed in places where there are major staff shortages.

Of the 16 respondents who had grown up in Sweden or partly resided in Sweden, only two perceived having experiences that could be linked to discrimination, and only one had experienced having their competence undervalued, and the respondents perceived reasons for this were lack of work experience in Swedish healthcare and having been educated abroad $(6 \%, n=16)$.

\section{Facilitating aspects}

Facilitating aspects and barriers corresponded to each other and are hence presented in the same table (Table 6). For example, lacking contacts was an identified barrier, whereas having contacts was an identified 
Table 6 Barriers to and facilitating aspects and strategies for entry into and advancement within the medical labour market in Sweden

\begin{abstract}
Barrier
Originates from another country and/or has a medical degree from abroad

Origin from another country was a perceived reason by $16 \%$ of the respondents ( $n=283$ ) for having one's competence undervalued during the job-seeking process compared to physicians with a medical degree from Sweden.

'They have said it straight out in the interview without knowing or knowing what knowledge I have. On several occasions I heard prejudices about the country I was trained in'.

Others did not believe that their medical knowledge was enough, which was a perceived reason for having competence undervalued by $11 \%$ of the respondents $(n=283)$. One respondent wrote: "I worked as a [names a specialty] for $[X X]$ years, unfortunately my experience became 'zero"'. To have a medical degree from abroad was a perceived reason for $6 \%$ of the respondents for having their competence undervalued. 'Worked as a junior doctor and had been promised a mandatory medical internship; however, physicians who had never worked as junior doctors got their mandatory medical internship before me, probably since they were educated in Sweden/EU'.

'There is many/almost everyone who does not trust foreign physicians'. 'Got to hear from a medical director at a geriatric clinic where I applied for a job that we know nothing, can do nothing, and that we are burden on the Swedish system, and that they do not even want to meet a doctor like us'.
\end{abstract}

\section{Having another ethnicity and/or religion or other belief}

Having another ethnicity and/or having another religion or other belief is not the same thing, but can be connected in how people perceive each other.

Of the respondents, 20\% perceived that they had been disfavoured related to discrimination by having another ethnicity, and 7\% perceived that they had been disfavoured related to discrimination by having another religion or other beliefs.

'Regarding Muslims and Arabs, they think we have a bad view on women'. 'I wear a veil'.

\section{Having a different name}

A name might imply one's origin.

'Personally, I believe that foreign names and ages can affect the application. I experienced that'.

'Arabic name is enough to get a no'.

\section{Insufficient language skills}

To not speak Swedish good enough was mentioned by $5 \%$ as one reason for having one's competence valued less than the competence of physicians educated in Sweden.

'Got several who replied that I need Swedish knowledge even if my email, C and everything is written in Swedish and they had never talked to me on the phone'
$+$

Facilitating aspect and strategy

Not all respondents were born abroad, but may have moved during childhood and then returned

'It has been an advantage being born and raised in Sweden and speaking Swedish fluently, in comparison to CPP peers'. Applying for Swedish citizenship

As a strategy to increase job opportunities, $11 \%$ of the respondents had applied for Swedish citizenship.

\section{Having experience from another country}

'My experience from my home country helped me a lot'.

Some respondents, $2 \%(n=7)$, had changed their name to a Swedishsounding name as a strategy for increasing opportunities to be employed.

Another strategy: 'I erased [name] from my name'.

\section{Learning the Swedish language}

Learning the Swedish language was mentioned by respondents as a acilitating aspect.

'I got my jobs because I did not have a strong accent and all of my

interviews have gone well due to that'.

Strategies used to learn the language:

* Listening to audiobooks

*Reading a lot in Swedish

*Speaking with Swedish people in general

*Using language-training apps

*Participating in Swedish language courses

*Work

Of those who had a position as a physician, 50\% perceived that speaking Swedish to Swedes was a very useful aspect that had increased opportunities for finding work as a physician in Sweden. Being married to a Swede was mentioned by one respondent as a facilitating aspect in learning the language, as they speak Swedish at home. The same respondent also mentioned that being married to a Swede had also increased possibilities to integrate into Swedish society.

In Sweden, different associations sponsor language cafés where migrants meet and speak, have coffee or tea with the aim of learning the Swedish language. Respondents had not participated in these events to a great extent, and most who had participated did not think of them as valuable for finding work.

Swedish language apps and apps with medical terminology and 
Table 6 Barriers to and facilitating aspects and strategies for entry into and advancement within the medical labour market in Sweden (Continued)

\begin{tabular}{|c|c|}
\hline Barrier & $\begin{array}{l}+ \\
\text { Facilitating aspect and strategy }\end{array}$ \\
\hline & $\begin{array}{l}\text { knowledge had not been used to any great extent, and respondents who } \\
\text { had used these kinds of apps in general did not perceive them as useful }\end{array}$ \\
\hline
\end{tabular}

\section{Having the wrong age}

It can be assumed that physicians from outside the EU/EEA in general are older than Swedish graduates when they compete for the mandatory medical internship and other positions in the medical field, such as specialty training positions.

Of the respondents, $8 \%$ perceived that they had been disfavoured related to discrimination based on age.

'Due to high age, they do not want to give [mandatory medical internship]'. Respondents also mentioned that it is more difficult to advance to specific specialties due to being too old.

Respondents' waiting time for the MMI might be related to their age.

Respondents with shorter waiting times were slightly younger:

10 months or less of waiting time $(n=59)$ : 37 years

11 months or more of waiting time $(n=120)$ : 41 years

\section{Having the wrong gender}

Of the respondents, $2 \%$ perceived that they had been disfavoured related

to the discrimination based on gender.

Of those who had perceived themselves to be disfavoured due to gender, the majority were women (13 of 17).

'They asked me about children and how many children I planned'. In comparison to all respondents, and regarding the mandatory medical internship, men were slightly over-represented in beginning their MMI quicker after having completed route 1 or route 2 (CPP) than women:

10 months or less of waiting time $(n=59): 59 \%$ men/41\% women

11 months or more of waiting time ( $n=120): 44 \%$ men/56\% women

\section{Lacking work experiences and work references from work in \\ Sweden}

Lacking work experience was a perceived reason by $18 \%$ of the respondents ( $n=283$ ) for having one's competence undervalued during the job-seeking process.

'I was told from someone who sits on HR at an employer (which I did not apply for) that job applications from foreign doctors are put in a separate folder which is different from Swedish educated, as they prefer doctors that are experienced in Swedish healthcare'.

'Not familiar with routines, the system'.

'Judgmental employers who will not give foreign physicians without any experience from the Swedish medical labour market'.

'Employers want to hire physicians with experience of Swedish healthcare'. Lacking work references was a perceived reason by $13 \%$ of the respondents ( $n=283$ ) for having one's competence undervalued during the job-seeking process.

\section{Work in the Swedish healthcare and/or medical field}

Before the CPP havingworked in the Swedish healthcare and/or medical field as, for example, an assistant nurse, nurse or physician assistant

This was in order to:

*Learn the language

* Learn and/or understand how the routines and system in Swedish healthcare work

*Develop contacts

${ }^{*}$ Get into or in touch with the healthcare sector

*Demonstrate skills

*Develop work references by showing competence during work before the CPP or during CPP internship.

*Have many work recommendations from different sites.

Regarding work in Swedish healthcare, as physicians in different positions or as other types of healthcare staff, respondents mentioned that they have struggled, taking difficult jobs, working hard, sometimes in uncomfortable working hours, and others have been on call at all times, taking jobs with a low salary in a specialty in which they preferred not to work.

Taking a job when over-qualified for it or with a lower salary Of the respondents, 20\% had taken a job beneath their qualifications. 'It was quite easy to get a job at a healthcare centre since there is always missing physicians'.

'Took the first job offered and accepted a very low salary in a specialty which I do not like'.

Doing research was mentioned by some respondents as an aspect that had increased their opportunities to get a job as a physician in Sweden. However, another MP had left work as a researcher in favour of an underqualified job in the healthcare sector just to be able to work as a physician later on.

\section{Positive approach}

Respondents also mentioned that one needs to be open-minded to new knowledge, be flexible, positive, nice and humble to increase the possibilities to get a job. Also mentioned was that one should adjust to society and not listen to those complaining about the system. 
Table 6 Barriers to and facilitating aspects and strategies for entry into and advancement within the medical labour market in Sweden (Continued)

\begin{tabular}{|c|c|}
\hline $\begin{array}{l}- \\
\text { Barrier }\end{array}$ & $\begin{array}{l}+ \\
\text { Facilitating aspect and strategy }\end{array}$ \\
\hline $\begin{array}{l}\text { To lack contacts is a very common barrier in the comments; some } \\
\text { examples: } \\
\text { 'I just sent my CV as I did not know that in Sweden you must have either } \\
\text { contacts or recommendations, which I am not used to from my home } \\
\text { country'. } \\
\text { 'It is difficult to get a job if you do not have any contact in healthcare'. } \\
\text { 'I had no contacts with the clinics which I applied for'. } \\
\text { One respondent brought up the topic of nepotism, friendship corruption } \\
\text { and bias. }\end{array}$ & $\begin{array}{l}\text { *Employers, developed during work before the CPP } \\
\text { *Workplaces, developed during the CPP internship } \\
\text { *CPP peers, developed during the CPP } \\
\text { *Family and relatives } \\
\text { *Friends } \\
\text { *Peers from the country of origin } \\
\text { *Mentors } \\
\text { *Having a personal network of Swedes } \\
\text { Contacts developed during the CPP were by more than one half of } \\
\text { respondents thought to have made it easier for them to get a job as a } \\
\text { physician in Sweden: partly, much or to a very much extent ( } n=236 \text { ). } \\
\text { 'Everyone who has contacts gets jobs faster. There are a large group of } \\
\text { physicians from the same country [mentions some countries] that help each } \\
\text { other a lot and give each other lots of information that others do not get'. } \\
\text { Strategies to find work without developed contacts } \\
\text { 'Sent email to all healthcare centres within [distance] from [city] to receive } \\
\text { my first temporary post as a junior doctor'. } \\
\text { 'Visited the employer at his workplace as a drop in and then either booked } \\
\text { time or had the opportunity to show my qualifications / grades and } \\
\text { presented myself as a person, and it has worked well for me and I got a job } \\
\text { fast - } 3 \text { weeks after my application -but I also could start earlier if I wanted } \\
\text { to'. } \\
\text { "Searched work actively / went to work to 'mingle' before the interview". } \\
\text { 'Actively contacted loads of employers in different specialties'. }\end{array}$ \\
\hline
\end{tabular}

High competition in the labour market regarding the mandatory medical internship, in certain parts of the country (cities) and for advancement within the labour market regarding some specialties Of the respondents, $70 \%$ lived in a big/bigger city in Sweden. Not being able to move due to family was mentioned by some respondents as a barrier to the labour market. For 15\% (41, $n=269)$, children living at home affected possibilities or willingness to move; for $29 \%$, children affected to a great extent; and for $19 \%$, partly. For $50 \%$ of the respondents, a partner affected the possibility or willingness to move to either a great extent or completely.

\footnotetext{
Administrative barriers

Respondent mentioned:

Lack of/or insufficient

*Information about the recertification process

*Clinical supervisors during different positions

*Medical internships (both before the CPP and the mandatory positions after the (PP)

${ }^{*}$ Cooperation between different authorities (such as the Public

Employment Service, migration board, universities and other labour office programmes)

*Education positions at CPP

The time it takes before being able to work as a physician in Sweden is mentioned by respondents. For example: 'If I could have gotten help with the language and a spot at the CPP directly, then I would not have been lost for 5 years'.

Also mentioned is the difference between non-EU/EEA physicians and EU physicians. EU physicians do not have to go through the same process as non-EU/EEA physicians.
}

\section{To move or commute}

'Aimed at work outside the city, in a rural area'.

II applied for work everywhere in [region]. I got a call for interviews from some clinics but got my first temporary position far from my home town. Despite young children at home, I accepted it'.

As a strategy to increase job opportunities, 37\% of the respondents had applied for a job outside their hometown.

"I worked in 3 different towns before I at last got an MMI".

Of the respondents having or who had had a mandatory medical internship position ( $n=179), 36 \%$ moved for it. Of those who moved ( $n=66$ of 156), $36 \%$ were women and $64 \%$ were men.

\section{Change specialty}

Of the respondents, 19\% had changed specialties to increase the opportunities for getting a job.

\section{Participating in interventions}

Public Employment Service and Public Employment Service office and labour office programme aimed at supporting newly arrived migrants to the labour market was by two-thirds not perceived as having made it easier for them to get a job as a physician in Sweden. The programme had been useful only for a few. A couple of open comments stated that the labour office did not help them, for example: 'The Public Employment Service's quick track sounds like a joke but hope this description depends on change since what I experienced in 2013-2014'.

${ }^{*}$ Courses for physicians educated abroad, to facilitate entrance to route 1 or 2.

Many participated in different courses, but only a few found them useful or valuable.

*Route 2 (CPP)

Some mentioned the CPP in general and some as having saved their career. Participating in the CPP is by some seen as a strategy to increase the possibilities to work as a physician in Sweden, as it is also one of the three routes for obtaining the Swedish licence to practice.

'The project in itself is very good, that we who do not come from the EU get a place in the Swedish healthcare by updating us how the healthcare system works, and we get to learn the medical terms required to meet a patient'.

However, employers being unfamiliar with the CPP was a perceived reason by $11 \%$ of the respondents $(n=283)$ for having one's competence undervalued during the job-seeking process.

*Route 1

Being able to switch from route 2 (the CPP) to route 1 , since it is 
Table 6 Barriers to and facilitating aspects and strategies for entry into and advancement within the medical labour market in Sweden (Continued)

\begin{tabular}{ll}
\hline- & + \\
Barrier & Facilitating aspect and strategy \\
\hline & perceived to decrease the time for obtaining the Swedish licence to \\
& practise. For some, the change of route meant that they did not need to \\
& complete the mandatory medical internship. \\
& *Help with CV and job application \\
& An MP commented that 'the right and interesting personal letter [in job \\
& application]' was a facilitating aspect for work. \\
& To receive help with CV and personal letter was thought as partly, much \\
& or very much to be valuable for increasing job opportunities by almost \\
& three-quarters of the respondents. \\
& Support \\
& *Bothers going through the same process \\
& *Being encouraged by mentor \\
\hline
\end{tabular}

CPP denotes Complementary Program for Physicians with a medical degree from outside the EU/EEA or Switzerland

*There are seven grounds for discrimination in Sweden: ethnicity, religion or other belief, sex, age, transgender identity or expression, disability and sexual orientation; the last three were not prominent in the data

facilitating aspect. In the same table, we also present different strategies used by the MPs for increasing opportunities for employment.

Respondents also had suggestions on what changes would better facilitate entry into the medical labour market: less bureaucracy, living in less segregated areas in which there is a mix of Swedes and foreigners, Swedish language courses, an introduction course on Swedish culture and mentality, more internships, increased CPP and MMI positions, developing a section for MPs within the physicians' union and employers being more willing to hire foreign physicians.

\section{Discussion}

We explored how MPs with a medical degree from outside EU/EEA after the CPP entered into and advanced within the medical labour market in Sweden as physicians, and we identified perceived barriers and facilitating aspects. We found that even when the MPs had increased their symbolic capital by having a medical education from one country and participating in the CPP in the new country, they still experienced barriers to entering and advancing within the Swedish medical field. These barriers were mainly due to having a medical degree from and/or originating from another country, and they could also be related to the grounds of discrimination and/or having one's competence undervalued.

Respondents mainly found their first positions via spontaneous job applications, during their CPP internship or via personal contacts. Our results are somewhat in line with previous research showing that MPs are approached with job offers during internships [8]. Respondents' first job was mainly as a junior doctor, even though the ideal position after the CPP was an MMI. Our results support the indication that it takes longer for MPs to obtain a Swedish medical licence [28]. For our respondents, the mean time to begin the MMI was
16.2 months in comparison to physicians with a medical degree from Sweden or elsewhere in the EU/EEA, who had a mean of 10.3 months of waiting time in 2017 [46]. The waiting time to begin the MMI in Sweden's largest urban region was 20.4 months for our respondents; for physicians educated in Sweden or elsewhere in the EU/ EEA, however, the waiting time was 18.6 months in 2017 [46]. These differences might be due to the difficulties MPs experience, which were explored in our study.

Our results show that the respondents perceived that employers during the job-seeking process undervalued their competence in contrast to that of physicians educated within the country. These results are also in line with research showing that even "where 'foreign' qualifications are formally recognized, employers invoke criteria such as the lack of local professional experience" [35]. MPs' symbolic capital might be formally acknowledged, but in the medical field, it does not seem to attain full recognition. MPs might be perceived as lacking needed 'national' capital and perhaps meet national-based protectionism [35], i.e. not being 'Swedish' enough. Employers might not know about the CPP or they may mistrust foreign competences, consciously or unconsciously (cf. [35]), just as employers do not always discriminate intentionally [20]. Our results can also be compared to research showing that employed MPs perceive their educations to be undervalued by their peers [22].

Almost one third of the respondents perceived having been disfavoured by employers in their job-seeking process for reasons related to discrimination. Specific combinations, such as age and country of origin, or gender and religion/or other belief, might generate more difficult barriers [47]. Experiences of being disfavoured due to reasons related to discrimination (regulated by law) and/or having one's competence undervalued (not regulated by law) seem to be intertwined in the creation of barriers to the medical field. Some reasons for not 
being offered a job might be difficult to grasp or report due to ambiguity. In this respect, other aspects may need to be considered: For instance, is one being discriminated against for not getting a job if that job requires sufficient language skills for patient safety reasons but the job candidate lacks those skills? Having insufficient language skills might be a reason for having one's competence undervalued and is usually related to being of another ethnicity. In Sweden, ethnicity is considered as a ground for discrimination.

Based on the respondents' experiences, our interpretation is that the medical field is segmented (cf. [23]) and that MPs as a group are hierarchically positioned lower in the Swedish medical field than physicians trained in the country. However, how they are individually and hierarchically positioned is a complex issue, since MPs are not a homogenous group. Country of origin, country of education or MPs' beliefs might affect how they are treated in the job application process [17-20]. Also, age and gender may also exert an influence. For example, internationally educated female health professionals appear to struggle more so than men [15, 33]. Individual characteristics influence routes (cf. [33]), and barriers might hence depend on several biographical aspects (cf. [8]).

We found that MPs perceived some aspects as being more facilitative of entering the Swedish medical field and that they had also tried different strategies. Having previously experienced the Swedish healthcare system prior to enrolling in the CPP as an assistant nurse was, for example, perceived as a facilitating aspect, as it helped develop knowledge about the Swedish healthcare field as well as Swedish language skills; these skills can be seen as national-specific and hence "can be converted into 'national capital', to legitimize belonging" [35], which might make getting a job easier.

Work in Swedish healthcare previous to enrolling in the CPP and internships during the CPP also seemed to increase opportunities to find work in the future, as the respondents received Swedish work references and developed useful contacts. It was perceived by many respondents that having contacts made it easier to get a job. Having contacts that leads to work can be seen as social capital, which is in turn a form of symbolic capital. Our interpretation is that respondents developed social capital (as in contacts leading to jobs) either strategically or unconsciously in Sweden during work or internships previous to or during the CPP. However, it is also our interpretation that MPs' possibilities for gaining social capital might be based on first demonstrating their competence in the Swedish healthcare/medical field by, for example, expressing knowledge about the Swedish healthcare system (cf. [35]); such aspects can be perceived as facilitating employment. Having a level of formal education equal to that of physicians educated in Sweden does not seem to be enough, as Salmonsson et al. suggested, because they also 'need to show that they are able to manage Swedish cultural codes in the health context' [23]. But we also found that some respondents found their first positions via other MPs participating in the CPP, and hence, CPP peers seemed to be transformed into social capital. Capital other than Swedish national-specific capital can thus be of importance for getting a job, as suggested by Blain et al. [33], who highlighted the support of international medical graduate peers and how both sharing one's migrant status and medical profession are of importance. The CPP seemed to increase MPs' networks and opportunities for finding employment, except for facilitating professional development with national-specific capital to fit the new country's needs and requirements. Research regarding internationally graduated nurses shows that participation in a bridging programme and having a social network seem to be good predictors for securing employment [48], and our results indicate that this might hold true for MPs. Our results are also in line with research showing that MPs after recertification are employed as physicians to a large extent [8].

As our interpretation is that MPs with a medical degree from outside the EU/EEA are, as a group, located hierarchically lower in the Swedish medical field than physicians with a medical education from Sweden, this probably explains why many respondents mentioned struggling to get a job and using different strategies to enter the medical field. Some mentioned working uncomfortable hours, being on call at all times or taking jobs with a low salary in a speciality in which they preferred not to work. Others had moved. MPs also changed specialties or took jobs they were over-qualified for. Those experiencing many difficulties probably also used multiple strategies (cf. [33]). In studies of migrants, it has been shown that one's name can be used by employers to sort job applications and that name changes can increase opportunities to be hired [20]. In fact, a few respondents in this study did just that, which unfortunately reflects submission to an oppressive norm. On the other hand, if it facilitates an MP's entrance into the labour market on an individual level, then it is understandable why it would be used as a strategy.

We found that barriers and facilitating aspects were in many cases two sides of the proverbial same coin. In other words, if developing language skills is facilitative, then being unable to speak that language is a barrier. Insufficient language is moreover one of the most common barrier identified in research $[8,19]$. We suggest that multiple forms of discrimination can coexist and that in such cases, the struggle to get a job is even harder. On the opposite side however, when MPs 
develop national-specific capital by, for example, developing language skills and increasing their knowledge about the Swedish healthcare field, then job opportunities considerably increase.

\section{Methodological considerations}

First, a limitation with this study was that it only included participants from route 2 . However, it is likely that our findings are pertinent to route 1 participants as well. Second, the study was based on self-reported data only, which can be biased; that said, subjective experiences and perceptions offer a preliminary step towards illuminating and addressing barriers and facilitating aspects.

\section{Implications for practice and future research}

By exploring and identifying aspects that influence the transition to a new country's medical field, interventions can be developed or refined, and policies can be informed. As employers may discriminate unintentionally, they might also undervalue the competence of MPs unconsciously. Therefore, it might be important to train employers to increase their awareness of their own behaviours and prejudices and to realise that even those with good intentions can create or reinforce barriers for MPs. At the societal and individual levels, it is important that MPs participating in bridging programmes find employment afterwards; otherwise, it is a waste of effort, competence and money. In addition, work is an important factor for integration and well-being. For these reasons, the transition between a bridging programme and employment should be as fast as possible.

To integrate language training and MMI in bridging programmes is a further recommendation for practice based on this study. More specified training in the jobseeking process may also be useful, i.e. when to apply, how to write an application and questions that might come up during a job interview. Our study further implies that language training, internship or auscultation opportunities would be useful as soon as possible upon arrival, thus even before bridging programmes.

Future studies could specifically explore route 1 participants with a large enough sample to make valid statistical comparisons regarding the selection of routes within groups of MPs. Also, a corresponding study in which physicians educated in Sweden are contrasted with MPs might elicit alternative perspectives and contribute to knowledge construction.

\section{Conclusion}

Having personal contacts in the medical field who can be used as social capital may increase job opportunities for MPs. An active development of a variety of contacts seems beneficial; this can be established during interventions, such as internships, and with spontaneous job requests or social networks. MPs have very limited opportunities to network in a new country's medical field during their training; consequently, this study revealed that they are at a disadvantage when entering and advancing within the medical labour market. MPs experience a variety of barriers while attempting to enter and advance within the Swedish medical labour market, partially due to reasons related to discrimination. Many MPs perceived having their competences undervalued due to their origin or education abroad. It is our interpretation that for optimal entry into the labour market, it is vitally important for MPs to get a job or internship as soon as possible within the medical field in order to gain proficiency in field-specific contexts, improve their language skills and develop contacts with colleagues and future employers.

\section{Abbreviations}

CPP: Complementary Program for Physicians with a medical degree from outside EU/EEA and Switzerland; EEA: European Economic Area; EU: European Union; MMI: Mandatory medical internship; MP: Migrant physician

\section{Acknowledgements}

We thank respondents of the questionnaire, experts who provided their expertise to the project, physicians involved in the cognitive interviews and respondents in the pretesting and the pilot testing of the questionnaire and the responsible for the CPP.

\section{Authors' contributions}

LS and TS designed the study. LS developed the questionnaire with support by TS, GHN, MÖ and PP. LS collected the data and performed the analysis with the support of TS, GHN, MÖ and PP. LS wrote the paper with the support of TS, GHN, MÖ and PP. All authors read and approved the final manuscript.

\section{Funding}

This work was supported by The Kamprad Family Foundation for Entrepreneurship, Research \& Charity, grant number 20170068. Webpage: http://familjenkampradsstiftelse.se/. The funders had no role in the study design, data collection, analysis, decision to publish or preparation of the manuscript.

\section{Availability of data and materials}

The dataset generated during and analysed during the current study are not publicly available due to ethical restrictions. The data is protected by confidentiality rules pursuant to the Swedish Public and Privacy Act, which means that no unauthorised person can access the data. This is to protect the participant's confidentiality and privacy. Any questions regarding the data can be emailed to linda.sturesson@ki.se.

Ethics approval and consent to participate

Ethical approval was received from the Regional Ethical Board in Stockholm, Sweden (2017/1717-31/5). Study participants gave consent before participation.

\section{Consent for publication}

Not applicable

\section{Competing interests}

The authors declare that they have no competing interests.

\section{Author details}

${ }^{1}$ Department of Learning, Informatics, Management and Ethics, Karolinska Institutet, 17177 Stockholm, Sweden. '2Department of Ethnology, History of 
Religions and Gender Studies, Stockholm University, 10691 Stockholm, Sweden. ${ }^{3}$ Department of Neurobiology, Care Sciences and Society, Karolinska Institutet, 17177 Stockholm, Sweden.

Received: 23 July 2019 Accepted: 10 September 2019

Published online: 15 October 2019

\section{References}

1. Covell $\mathrm{CL}$, Neiterman E, Bourgeault IL. Scoping review about the professional integration of internationally educated health professionals. Hum Resour Health. 2016:14:12

2. Lineberry M, Osta A, Barnes M, Tas V, Atchon K, Schwartz A. Educational interventions for international medical graduates: a review and agenda. Med Educ. 2015;49(9):863-79.

3. Lockyer J, Hofmeister M, Crutcher R, Klein D, Fidler H. International medical graduates: learning for practice in Alberta, Canada. J Contin Educ Health Prof. 2007;27(3):157-63.

4. Morrow G, Rothwell C, Burford B, Illing J. Cultural dimensions in the transition of overseas medical graduates to the UK workplace. Medical Teacher. 2013;35(10):E1537-E45.

5. Sockalingam S, Hawa R, Al-Battran M, Abbey SE, Zaretsky A. Preparing international medical graduates for psychiatry residency: a multi-site needs assessment. Acad Psychiatry. 2012;36(4):277-81.

6. Sturesson L. Utvärdering och uppföljning: Kompletteringsutbildningen för läkare med examen från land utanför EU/EES, 2009-2014. Stockholm: Karolinska Institutet, Department of Learning I, Management and Ethics; 2016.

7. Chen PG, Curry LA, Bernheim SM, Berg D, Gozu A, Nunez-Smith M. Professional challenges of non-U.S.-born international medical graduates and recommendations for support during residency training. Acad Med 2011;86(11):1383-8.

8. Herfs PGG. International medical graduates in the Netherlands. Utrecht: Utrecht University; 2011.

9. Kuusio H, Lamsa R, Aalto AM, Manderbacka K, Keskimaki I, Elovainio M. Inflows of foreign-born physicians and their access to employment and work experiences in health care in Finland: qualitative and quantitative study. Hum Resour Health. 2014;12:41.

10. Neiterman E, Bourgeault IL, Covell CL. What do we know and not know about the professional integration of international medical graduates (IMGs) in Canada? Healthcare policy = Politiques de sante. 2017;12(4):18-32.

11. Klingler C, Marckmann G. Difficulties experienced by migrant physicians working in German hospitals: a qualitative interview study. Hum Resour Health. 2016;14(1):57.

12. Eriksson E, Berg S, Engstrom M. Internationally educated nurses' and medical graduates' experiences of getting a license and practicing in Sweden - a qualitative interview study. BMC Med Educ. 2018;18(1):296

13. Skjeggestad E, Gerwing J, Gulbrandsen P. Language barriers and professional identity: a qualitative interview study of newly employed international medical doctors and Norwegian colleagues. Patient Educ Couns. 2017;100(8):1466-72.

14. Skjeggestad E, Norvoll R, Sandal GM, Gulbrandsen P. How do international medical graduates and colleagues perceive and deal with difficulties in everyday collaboration? A qualitative study. Scand J Public Health. 2017; 45(4):428-35.

15. Davda LS, Gallagher JE, Radford DR. Migration motives and integration of international human resources of health in the United Kingdom: systematic review and meta-synthesis of qualitative studies using framework analysis. Hum Resour Health. 2018;16(1):27.

16. Ahmed A. Etnisk diskriminering - vad vet vi, vad behöver vi veta och vad kan vi göra? Ekonomisk debatt. 2015;43:18-28.

17. Bursell M. In: migrationsstudier Df, editor. Etnisk diskriminering på den svenska arbetsmarknaden. I: Vägen till arbete. Stockholm: Delegationen för migrationsstudier; 2017. p. 40-51.

18. Le Grand C, Szulkin R. Permanent disadvantage or gradual integration: explaining the immigrant-native earnings gap in Sweden. Labour. 2002; 16(1):37-64.

19. Huijskens EG, Hooshiaran A, Scherpbier A, van der Horst F. Barriers and facilitating factors in the professional careers of international medical graduates. Med Educ. 2010;44(8):795-804.

20. Tibajev A. Utrikesfödda på arbetsmarknaden i Sverige: en forskningsöversikt. [Foreign-born in the labour market in Sweden: a research over view.]:
Linköping: Linköping University, Institute for Research on migration, Ethnicity and Society; 2016.

21. Povrzanovic Frykman M, Öhlander M. Högutbildade migranter i Sverige. En introduktion [Highly Skilled Migrants in Sweden. An Introduction]. In: Povrzanovic Frykman MÖ, Magnus, editors. Högutbildade migranter i Sverige [Highly Skilled Migrants in Sweden]. Lund, Sweden: Arkiv förlag; 2018

22. Neiterman E, Bourgeault IL. The shield of professional status: comparing internationally educated nurses' and international medical graduates' experiences of discrimination. Health (London). 2015;19(6):615-34.

23. Salmonsson L, Mella O. Cultural demands on skilled immigrants, a devaluation of human capital. The case of immigrant physicians in Sweden. Nord J Migr Res. 2013:3(1):3-9.

24. Sturesson L, Ohlander M, Nilsson G, Stenfors T. Migrant physicians' conceptions of working in rural and remote areas in Sweden: a qualitative study. PLoS One. 2019;14(1):e0210598.

25. Terry DR, Le Q. Challenges of working and living in a new cultural environment: a snapshot of international medical graduates in rural Tasmania. Aust J Rural Health. 2015:1-5.

26. Wenghofer EF, Timony PE, Pong RW. A closer look at Ontario's northern and southern rural physician demographics. Rural Remote Health. 2011:11(1):11.

27. Vahedi S. Den som väntar på en AT väntar för länge. SYLF:S nationella kartläggning av AT-platser. Stockholm: SYLF - Sveriges Yngre Läkares Förening; 2017.

28. Nilsson S, Viberg A. Etablering och sysselsättning för dem som genomgått kompletterande utbildning för personer med avslutad utländsk utbildning. Stockholm: Universitetskanslerämbetet; 2016. Contract No:: 12

29. Bourdieu P. The Forms of Capital. In: Richardson J, editor. Handbook of Theory and Research for the Sociology of Education. Westport: Greenwood; 1986. p. 15-29.

30. Carlhed C. Fält, habitus och kapital som kompletterande redskap i professionsforskning. Socialvetenskaplig tidskrift. 2011;18(4):283-300.

31. Broady D. Sociologi och epistemologi. Om Pierre Bourdieus författarskap och den historiska epistemologin. (Sociology and Epistemology. On Pierre Bourdieu's work and the historical epistemology). 2nd ed. Stockholm: HLS Förlag; 1991.

32. Tovatt C. In: migrationsstudier Df, editor. Nätverksrekryteringens betydelse för utlandsföddas arbetslivsmöjligheter. I: Vägen till arbete. Stockholm: Delegationen för migrationsstudier; 2017. p. 52-63.

33. Blain MJ, Fortin S, Alvarez F. Professional journeys of international medical graduates in Quebec: recognition, uphill battles, or career change. J Int Migr Integr. 2017;18(1):223-47.

34. Wolanik Boström K, Öhlander M. A troubled elite?: stories about migration and establishing professionalism as a Polish doctor in Sweden. Bielefeld: COMCAD - Center on Migration, Citizenship and Development; 2012. Contract No: 110/2012

35. Erel U. Migrating cultural capital: Bourdieu in migration studies. Sociol J Br Sociol Assoc. 2010:44(4):642-60.

36. Artino AR Jr, La Rochelle JS, Dezee KJ, Gehlbach H. Developing questionnaires for educational research: AMEE guide no. 87. Med Teach. 2014;36(6):463-74

37. Artino AR Jr, Gehlbach H. AM last page. Avoiding four visual-design pitfalls in survey development. Acad Med. 2012;87(10):1452.

38. Artino AR Jr, Gehlbach H, Durning SJ. AM last page: avoiding five common pitfalls of survey design. Acad Med. 2011;86(10):1327.

39. Sullivan GM, Artino AR Jr. How to create a bad survey instrument. J Graduate Med Educ. 2017;9(4):411-5.

40. Feilzer MY. Doing mixed methods research pragmatically: implications for the rediscovery of pragmatism as a research paradigm. J Mixed Methods Res. 2010;4(1):6-16.

41. Rich JL, Chojenta C, Loxton D. Quality, rigour and usefulness of free-text comments collected by a large population based longitudinal study ALSWH. PLoS One. 2013:8(7)

42. Garcia J, Evans J, Reshaw M. "Is there anything else you would like to tell us" - methodological issues in the use of free-text comments from postal surveys. Qual Quant. 2004;38(2):113-25.

43. Braun V, Clarke V. Using thematic analysis in psychology. Qual Res Psycol. 2006:3:77-101.

44. Elo S, Kyngas $H$. The qualitative content analysis process. J Adv Nurs. 2008; 62(1):107-15.

45. SFS 2008:567. Diskrimineringslag. [Discrimination Act] Stockholm: Arbetsmarknadsdepartementet [Ministry of Employment]. 
46. Vahedi S. SYLF:S väntetidsrapport 2017. Underläkare - var god dröj. Stockholm: SYLF - Sveriges Yngre Läkares Förening; 2017.

47. Inte bara jämställdhet. Intersektionella perspektiv på hinder och möjligheter i arbetslivet. [Not just equality. Intersectional perspectives on obstacles and opportunities in working life]. Stockholm: Delegationen för jämställdhet i arbetslivet; 2014. Contract No.: SOU 2014:34

48. Covell CL, Primeau MD, Kilpatrick K, St-Pierre I. Internationally educated nurses in Canada: predictors of workforce integration. Hum Resour Health. 2017;15(1):26.

\section{Publisher's Note}

Springer Nature remains neutral with regard to jurisdictional claims in published maps and institutional affiliations.

Ready to submit your research? Choose BMC and benefit from:

- fast, convenient online submission

- thorough peer review by experienced researchers in your field

- rapid publication on acceptance

- support for research data, including large and complex data types

- gold Open Access which fosters wider collaboration and increased citations

- maximum visibility for your research: over $100 \mathrm{M}$ website views per year

At $\mathrm{BMC}$, research is always in progress.

Learn more biomedcentral.com/submissions 